\title{
Analysis of the Teaching Reform of Business Administration Based on the Training of Applied Talents
}

\author{
Binbing Zhang
}

Anhui University of Economic Management, Anqing 230001, Anhui, China.

Project: Anhui Institute of Economics and Management College-level key teaching and research project "based on vocational skills competition to create a new high-level staff business enterprise management professional practice teaching model Yjjyxm201801.

Abstract: The rapid development of the business management industry has made colleges and universities gradually recognize the importance of cultivating applied-skilled talents, and through the analysis of the development context of the market economy, they have made corresponding improvements to the teaching work, in order to establish a High-quality applied classrooms required by the position.

Keywords: Business Administration; Higher Education; Teaching Reform; Applied Talents

The rapid development of the market economy has ushered in a new wave of competition in the industry. Therefore, it has also imposed higher standards on the professionalism and application skills of business management personnel. Colleges and universities need to cultivate high-quality talents that meet the requirements of social positions. Therefore, when conducting business management teaching, teachers need to combine the actual classroom development to find specific ways that hinder the smooth improvement of teaching effectiveness.

\section{The main reason for the restriction of business management classroom in colleges and universities}

\subsection{The teaching objective is ambiguous}

As the important content for maintaining the future development of the enterprise, business management capabilities are important. Therefore, with the development of the times and the innovation of the market economy, people need innovative business management talents who are familiar with the business management process. The requirements are getting stricter. But the reality is that many teachers in colleges and universities do not formulate teaching goals in accordance with the actual market economy needs when conducting teaching work. Instead, they still use the scope of textbook exam outlines as the focus of teaching work under the constraints of old teaching perspectives. Under the circumstances that such teaching target positioning is difficult to coordinate with social development, not only is it difficult for students to have high professional and practical abilities, but it also seriously affects the orderly development of normal teaching work, which makes it difficult for business management education to achieve better development.

\subsection{The lack of attention in the practical classroom}

As a discipline that requires students to have strong management skills, speculative skills and practical skills, social positions require not only talents with rich professional knowledge reserves, but also application-oriented talents who can apply knowledge to practical situations. Many business administration teachers in colleges and universities often focus too much on the teaching of professional knowledge when teaching, and they lack the importance of practical classrooms. This will not only make the students lack the corresponding practical platform, unable to apply the knowledge to the actual situation, and 
the accumulated knowledge content is also difficult to adapt to the constantly changing market economic environment. Under such circumstances, not only are students' learning initiative severely constrained, but teaching effectiveness is also difficult to effectively improve, leading to serious obstacles to the smooth development of teaching reform.

\section{Specific ways of cultivating application-oriented talents in business management classroom of colleges}

\subsection{Design teaching objectives in conjunction with market development}

In order to ensure that colleges and universities can cultivate application-oriented talents that meet the requirements of society, professional teachers of business administration need to analyze the actual situation of market development and the future prospects of industry development through planned analysis of business management To improve the teaching objectives, students can not only complete the mastery of knowledge in the process of learning knowledge, but also grasp the development prospects of the industry to exercise practical ability and become an application-oriented talent that meets the needs of the post. For example, with the advent of the Internet era, talents in various industries need qualitative analysis, computer processing, quantitative analysis and English application ability. Teachers need to be able to target students' comprehensive skills and professional qualities when designing teaching goals. Only through upgrading can students have comprehensive skills and be able to participate smoothly in future employment.

\subsection{Create a practical platform in combination with teaching practice}

Due to the strong practicality and application of the business management professional courses, colleges and universities in order to cultivate application talents that meet the needs of enterprises should combine the specific development of the school and innovate a broader practice platform for students. For example, the school can cooperate with famous local enterprises. Through the introduction of the school-enterprise cooperation model, it provides students with a professional training platform so that they can regularly participate in enterprise post training activities and be more aware of their own existence. Problems, and accumulate work experience through continuous training, and grow into business management talents who meet the standards of enterprise job requirements.

\section{Combine students' need to exercise their thinking ability}

College students are active in thinking, so teachers should proceed from the actual learning needs of students when teaching, in order to ensure the smooth progress of teaching activities in the process of respecting their individual development. Therefore, the talent cultivation model of business management major should also start from respecting the learning needs of students, and through the exercise of their speculation ability, students can actively explore knowledge in the process of knowledge learning and apply it to solve Actual problem. This not only can effectively improve its own application ability, but also in the process of improving students' professional qualities, so that they can become business management talents that meet the needs of social development. In addition, teachers also need to maintain close communication with students and design a lesson plan for them from the perspective of students, in order to effectively stimulate their speculation ability and learning initiative, and promote the successful completion of the education reform of business administration majors.

\section{Conclusion}

With the advent of the information age, people gradually realize the importance of applied talents. Therefore, the business administration major of colleges and universities is an important base for cultivating business talents in the new era. When teaching, teachers should not blindly carry out teaching activities under the constraints of backward education concepts, but need to combine the background of social development to make While completing professional knowledge learning, students can grow into applied talents that meet the needs of their positions.

\section{References}

1. Wang JY. Discussing the problems and solutions of practical teaching in business administration majors. Liaoning Economic Vocational and Technical College. Journal of Liaoning Economic Management Cadre College 2020; (02): 115-117.

2. Ma XJ, Jia NN. Exploration of "Curriculum Ideology and Politics" teaching in the undergraduate business administration major of open education_- Taking the course of "Modern Management Topics" as an example. Journal of Xinjiang Radio and TV University 2020; 24(01): 25-29.

3. Wang CJ. Reform and practice of experimental teaching and laboratory construction for undergraduates majoring in business administration based on the goal of cultivating applied talents—-Taking Northwest University for Nationalities as an example. Accounting of Chinese Township Enterprises 2019; (11): 287-288. 